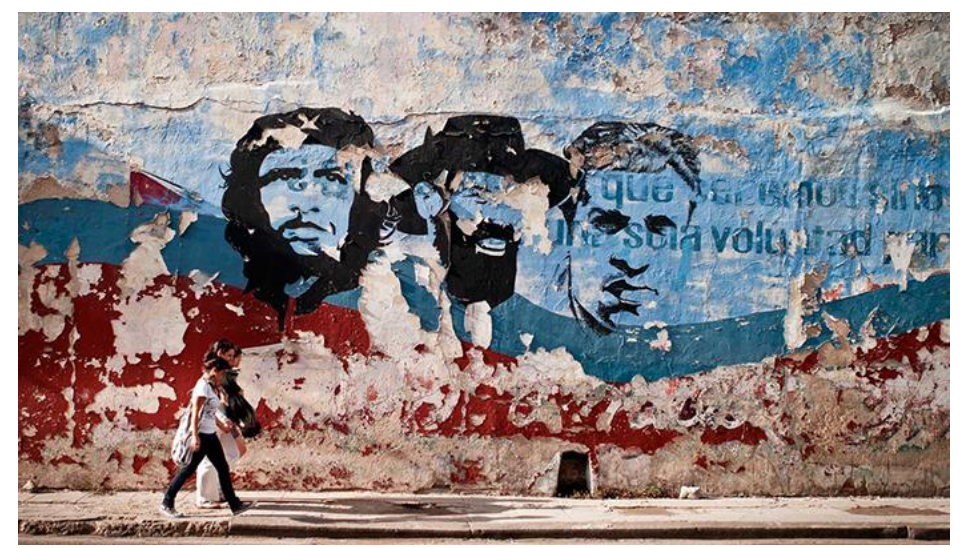

\title{
Quando a pauta é Cuba: o jornalista assujeitado às suas evidências
}

When the agenda is Cuba: the journalist subjected to their evidences

Juliana Sangion $^{1}$ Amanda Cotrim ${ }^{2}$

Resumo: No presente artigo, refletimos sobre o modo como a ideologia se manifesta na linguagem. De maneira específica, analisamos as condições de produção do vídeo Impressões de Cuba, produzido pela Globo News, na semana do dia 17 de dezembro de 2014, quando Cuba e os EUA reataram suas relações diplomáticas. Consideramos para a nossa análise dois fatores fundamentais: o sujeito (jornalista) e a situação, na tentativa de compreender a produção discursiva e seus efeitos de sentido no vídeo sobre Cuba. O presente artigo defende que, para o jornalista, tomado por sua experiência direta e imediata da realidade, as coisas na Ilha já chegam, pelo imaginário, como significado evidente. Antes de ir a Cuba, a ilha já chegara como imagem para o sujeito, que deixa escapar, pela linguagem, seu posicionamento no discurso sobre Cuba.

Palavras-chave: Análise de discurso, Ideologia, Documentário, Globo News, Cuba

Abstract: Abstract: In this article, we discuss how the ideology is manifested in language. Specifically, we analyze the production conditions of the video Impressões de Cuba, produced by Globo News, in the week of December 17th, 2014 when Cuba and the United States resumed diplomatic relations. Our analysis considers two key factors: the subject (the journalist) and the situation, in an attempt to understand the meanings produced about Cuba by the video. The article argues that, taken by his direct and immediate experience of reality, things on Cuban island already come, by the imaginary, as a clear meaning to the journalist. Even before going to Cuba, the island has arrived as an image for the subject, which lets out through the language, his position in the discourse about Cuba.

Keywords: Discourse analysis, Ideology, Documentary, Globo News, Cuba

\footnotetext{
${ }^{1}$ Doutora em Multimeios pela Universidade Estadual de Campinas (UNICAMP) e Professora no Centro de Linguagem e Comunicação da Pontifícia Universidade Católica de Campinas. Email: julisangion@yahoo.com. Endereço institucional: PUC Campinas. Campus I - Centro de Linguagem e Comunicação. Rodovia D. Pedro I, Km 136. Campinas - SP, 13086-900.

${ }^{2}$ Mestre pelo Laboratório de Estudos Avançados em Jornalismo, com ênfase em Análise de Discurso, no Instituto de Estudos da Linguagem (UNICAMP). Email: amandacotrim87@ gmail.com; Endereço: Cidade Universitária Zeferino Vaz - Prédio V da Reitoria- Barão Geraldo, Campinas - SP, 13083-970.
} 
A trajetória metodológica que aqui percorremos está amparada num estudo de caso do canal fechado Globo News, da emissora de televisão Rede Globo, o qual realizou o documentário ${ }^{3}$ Impressões de Cuba, em Havana, na semana do dia 17 de dezembro de 2014, quando Cuba e os Estados Unidos anunciaram o restabelecimento de suas relações diplomáticas. Tomamos como principais referências as teorias do documentário (NICHOLS, 2005), (RAMOS, 2008), do jornalismo (LAGE, 1982), além da análise de discurso materialista (PÊCHEUX, 1975, 1995, 1999), (ORLANDI, 1994, 1999, 2008); esta última se apresentando como uma teoria crítica da linguagem.

Sabemos que o conceito de representação é tema de muitas discussões no campo dos estudos da linguagem, oferecendo espaço para posições diversas sobre as relações entre linguagem e mundo. Também no campo dos estudos audiovisuais, a noção de representação no documentário ocupa grande parte das discussões. Não podendo abarcar todas essas discussões, nos limitaremos, neste artigo, a pensar sobre as representações discursivas, a partir de alguns conceitos, como condições de produção: a notícia, o sujeito e a ideologia, que por sua vez se registram na linguagem do vídeo da Globo News. Como condições de produção (CP), entendemos as condições históricas (a memória discursiva) e as imediatas (a produção do vídeo). No decorrer do texto, apresentaremos como a linguagem do vídeo Impressões de Cuba produz representações sobre a Ilha A sequência discursiva que analisaremos é um recorte verbal do vídeo. Não será uma análise da materialidade discursiva em seu conjunto, mas apenas do verbal, dada a complexidade do material. Antes, contudo, entendemos que é necessário refletir sobre a noção de documentário e os seus efeitos de sentido na relação com o canal de TV Globo News.

Quando assistimos a documentários, esperamos, por meio de códigos espectatoriais ${ }^{4}$, estarmos diante de uma produção que cumpre certo papel. Geralmente relacionamos documentários a produções em que a temática abordada seja mais profunda; cujas etapas de realização sejam fruto de um trabalho de pesquisa mais

\footnotetext{
3 Documentário é o termo que a emissora de TV utiliza, mas ao longo do artigo vamos tentar compreender se realmente se trata de um documentário.

4 Referimo-nos não apenas a aspectos estruturais e procedimentos estilísticos próprios do campo documental, mas também ao conjunto de postulados que definem o modo de enunciar asserções sobre o mundo histórico.
} 
complexo. Ou seja, a ideia é que os documentários estariam mais próximos da realidade ${ }^{5}$.

Nesse artigo, refletiremos sobre o documentário como discurso. Isto é, as opções estéticas, a narrativa, a escolha de quem fala no documentário (e de quem não fala): tudo isso para nós é discurso, que por si é uma marca de posição. O documentário é sempre um fato de linguagem. Compreendê-lo dessa forma retira qualquer neutralidade sobre esses elementos.

Já a reportagem para o telejornal, enquanto gênero audiovisual, segue um modelo diferente, que por sua vez produz outros efeitos de sentido. No padrão televisivo, os acontecimentos, fragmentados enquanto notícias, por meio de uma narrativa, estão diariamente presentes na vida das pessoas, mesmo quando elas escolhem não ver televisão.

A impressão impagável de que o que se vê é real justamente por ser visto por todos é o que constitui o valor da comunidade que chamamos de audiência. E se todos veem a garantia existencial de que não estamos só vale mais ainda (TIBURI, 2011, p. 32).

Habituado a ver a "realidade ${ }^{6}$ recortada todos os dias, o sujeito/público percebe no documentário uma possibilidade para ter acesso a sentidos outros. Diferente do jornalismo, o documentário não se sustenta pelo discurso da objetividade ou até mesmo da imparcialidade. Ao contrário, o efeito é de que o documentário estaria autorizado a falar sobre ${ }^{7}$, sem amarras financeiras, comerciais e ideológicas, como existe na dinâmica da produção televisiva comercial. Os documentários exporiam suas subjetividades, aproximar-se-iam do público, produzindo humanização para a sua obra. A humanização é um efeito de sentido do documentário.

\footnotetext{
${ }^{5} \mathrm{O}$ conceito de realidade tem sido objeto de estudos nos diferentes campos do saber. Os documentários surgem, num primeiro momento histórico, do interesse em registrar o que seria a realidade, distanciandose, assim, do cinema de ficção da época. Nos anos 1920, o crítico e documentarista inglês John Grierson definiu os documentários como o "tratamento criativo da realidade (ou atualidade)". Adotamos o conceito de representação da realidade, ou seja, ao representar uma realidade, o diretor estaria escolhendo uma das muitas maneiras possíveis de perceber, de ver e de mostrar diferentes situações do mundo histórico. Na contemporaneidade, a produção documental tem dialogado bastante com a ficção e podemos dizer que, hoje, os documentários são percebidos como uma construção coletiva de significados, em que existe a contribuição subjetiva do autor, com suas interferências em todas as etapas.

${ }^{6}$ No jornalismo, podemos entender o conceito de realidade a partir de alguns critérios que regem o trabalho dos jornalistas no decorrer do processo de produção da notícia, quais sejam: imparcialidade, neutralidade e objetividade.

${ }^{7}$ É no 'discurso sobre' que se trabalha o conceito de polifonia. Ou seja, o 'discurso sobre' é um lugar importante para organizar as diferentes vozes (dos discursos 'de'). Assim, o discurso sobre o samba, o discurso sobre o cinema são parte integrante da arregimentação (interpretação) dos sentidos dos discursos do samba, do cinema, etc. (...). Ele organiza, disciplina a memória e a reduz (ORLANDI, 2008, p. 44).
} 
Levar o documentário para dentro da casa das pessoas, no ambiente doméstico, como tentou fazer a Globo News, interfere na recepção, aproximando esses três lugares: o documentário, o espectador e os documentaristas. Assim, veremos que em Impressões de Cuba, a narrativa frui para o espectador de duas maneiras: tanto autorizando o sujeito/jornalista a construir asserções eticamente comprometidas com os personagens protagonistas da história que conta, como respaldada pela própria noção de documentário ${ }^{8}$.

\section{Documentário ou reportagem?}

Como abordamos, dizer que uma produção audiovisual é um documentário ou uma reportagem produz efeitos de sentidos diferentes, por isso é importante refletir sobre esse lugar: o documentário. Uma das principais características que diferenciam documentários e reportagens diz respeito ao roteiro. Entender o funcionamento desse elemento em ambas as produções pode ajudar a compreender a estrutura do objeto da presente análise.

Em Jornalismo praticamente não há roteiro prévio. O que existe é uma pauta, elemento norteador do trabalho do repórter. Quando comparada ao roteiro de um documentário, a pauta pode ser considerada muito mais fechada do que o primeiro. Amplamente discutido nas chamadas reuniões de pauta, esse elemento jornalístico está inserido dentro de uma dinâmica de produção cujo fim é a notícia ${ }^{9}$. Nesse sentido, devemos considerar que as chefias nas redações de TV trabalham com a seleção de assuntos que interessam ou não, a partir dos seus critérios de noticiabilidade e do conceito de valor-notícia (LAGE, 1982). É preciso dizer que a pauta considera, além dos valores-notícia, também a linha editorial da emissora e não raro seus interesses econômicos. Assim sendo, a pauta já nasce limitada dentro dessa estrutura de produção da notícia. Dessa maneira, uma ideia só se transforma em pauta se necessariamente tiver sido limitada, do ponto de vista da definição prévia de um enfoque que faça sentido em certo programa, para certo público, em certo horário, que por sua vez faça sentido na

\footnotetext{
${ }^{8}$ O campo da produção documental possui fronteiras, seja com o jornalismo, com o cinema de ficção ou outras, e é importante pontuar que o fato de as fronteiras do documentário serem flexíveis não quer dizer que elas não existam. Flexionar tais fronteiras implica em reconhecer a criação de outros sentidos sobre essa linguagem.
} 
grade geral de determinada emissora. Portanto, o jornalismo recorta, e recortar é definir os limites da abordagem de determinado assunto para transformá-lo em notícia.

Por outro lado, a pauta também é o lugar onde se manifesta a violência simbólica do não-dito. "Aquilo que não é dito é o silêncio que divide o que se sabe daquilo que não se sabe no jogo de poder que sustenta efeitos de sentido: o silenciamento que a acompanha" (ORLANDI, 2008, p. 24). Não estamos aqui dizendo que a pauta deveria ser $\mathrm{x}$ ou $\mathrm{y}$, estamos tentando refletir a respeito do que ela é. Os acontecimentos, fragmentados enquanto notícias, fazem sentido quando são conectados à memória discursiva, ao já lá dos assuntos em pauta. "O discurso jornalístico contribui na constituição do imaginário e na cristalização da memória do passado e na construção da memória do futuro" (MARIANI, 1996, p. 64).

Ao levar a produção de documentários para o âmbito de emissoras de televisão, ela fica sujeita a abordagens que a aproximam da produção noticiosa diária, não apenas em relação aos valores-notícia citados acima, mas também, e principalmente, às rotinas de produção, tais como prazos (deadlines) geralmente curtos, estrutura técnica e equipe de profissionais que possui um olhar treinado ${ }^{10}$ muito mais jornalístico que documental. Se considerarmos os documentários como resultado de um processo criativo do cineasta, cujas escolhas marcam a sua apropriação imaginária sobre o real por uma consciência subjetiva, que inclusive vão orientar o enfoque (PUCCINI, 2009, p.15), podemos afirmar que na comparação com produções documentais autônomas, documentários realizados por emissoras de televisão adquirem características muito particulares.

O fato de ser um discurso sobre o real e utilizar imagens in loco são características que aproximam o documentário do discurso jornalístico. A nosso ver, contudo, ele não é um gênero jornalístico. Enquanto o jornalismo busca um efeito de objetividade ao transmitir as informações, no documentário predomina um efeito de subjetividade, evidenciado por uma maneira particular do autor/diretor contar a sua história. Por isso dizemos que o documentário é um gênero essencialmente autoral (MELO, 2002, p.27-28).

Em documentário - que não aqueles encomendados ou produzidos por emissoras de televisão -, os roteiros são em sua grande maioria abertos. Isso porque documentários geralmente são realizados a partir da ideia de um diretor. Ideia essa,

\footnotetext{
${ }^{10}$ Entendemos como olhar treinado as práticas de linguagem, que produzem um efeito de evidência (PÊCHEUX, 1988) sobre o modo de se fazer jornalismo ou documentário.
} 
ainda que possua elementos concretos e indícios que a comprovem, que permanece crua no sentido de não sofrer nenhuma limitação prévia, a não ser pelas discussões com a própria equipe de produção do documentário, mesmo que saibamos que a limitação se dá pelo imaginário e pela ideologia, inevitavelmente.

Daí é possível considerar que o tempo necessário para maturação do roteiro de um documentário é mais profundo e longo do que o tempo entre a sugestão de pauta e a pauta em si, no Jornalismo. Tal maturação acontece exatamente durante a produção do documentário, ou seja, na captação das imagens, na gravação das diversas situações e, principalmente, na coleta dos depoimentos dos personagens e na edição. É possível e bastante provável que haja mudanças, imprevistos, novas ideias, que possibilitem enriquecer a produção ou até alterar o enfoque previamente definido.

No campo das produções audiovisuais, sejam documentários ou reportagens, estamos diante de um processo discursivo, que produz e faz circular sentidos. Tanto um quanto o outro produzem um efeito de realidade que é construído na materialidade significante da organização desse discurso fílmico. Mas, se por um lado é o discurso sobre o real o ponto de aproximação entre jornalismo e documentário, por outro, vários são os fatores que os distanciam.

O percurso (de roteirização no documentário) é marcado pela perspectiva daquilo que está por vir, a captura de um real que gradualmente vai sendo moldado até se transformar em filme. Estamos falando da construção de um discurso sedimentado em ocorrências do real. A atividade de roteirização em documentário é a marca desse esforço de aquisição de controle de um universo externo, de remodelação de um real nem sempre prenhe de sentido (PUCCINI, 2009, p. 16).

É justamente no seu tempo de maturação que o documentário se produz. O documentário tira proveito dessa condição de produção, enquanto a reportagem praticamente nasce com a pauta e é produzida para dar conta desta. O tempo de maturação de um documentário, portanto, é uma condição de produção importante a ser considerada.

No jornalismo, o tempo de maturação, pelo seu caráter industrial é outro. Situação bastante comum nas redações das emissoras de televisão são repórteres nas coberturas externas (fora da redação) preocupados em conseguir depoimentos que apenas corroborem a ideia da pauta e dentro do prazo estabelecido, desconsiderando 
novas abordagens que as entrevistas possam trazer. Nesse caso, estão em jogo dois modos de produção sobre o real:

No documentário é preciso saber escutar, respeitar o tempo da narrativa do outro. O que nem sempre se faz no cotidiano do jornalismo diário. Lidar com o tempo (ou a falta dele) é algo que os jornalistas aprendem, mas compreender a marca desse tempo no interior de uma narrativa documentária é sempre um desafio (...) (TOMAIM. In: SOSTER, 2015, p.184).

Esse embate de sentidos sobre o real do telejornalismo e do documentário, discursivamente, diz que o documentário pode extrapolar o campo das descrições e se aprofundar nas questões colocadas no vídeo, apresentando diversas vozes, na tentativa de humanizar o documento audiovisual. E, mais que isso, o documentarista pode promover o confronto com o entrevistado, instigando-o a rever posicionamentos ou lançando desafios. O confronto possibilita que o documentário não "seja apenas o lugar onde o depoente 'ganha o direito de voz', mas um produto audiovisual cujo alicerce é o embate entre documentarista e personagem" (SOUZA, 2009, p.170).

Outra condição que diferencia as produções em telejornalismo do documentário é a noção de autoria. Discursivamente, os documentários são a materialidade da realização de uma ideia, que pode ter nascido $^{11}$ de uma ou mais pessoas, organizações ou instituições, e são produzidos a partir de um olhar muito específico sobre determinado(s) aspecto(s), cujo compromisso é diferente do jornalismo, qual seja mostrar vários pontos de vista controversos sobre um mesmo tema ou assunto, além do compromisso com os mitos da imparcialidade e neutralidade.

Já pontuamos que os documentários não são reproduções da realidade, mas representações sobre o mundo histórico e social, ou seja, versões sobre. A noção de representação é aqui entendida como aquele que não se propõe a ser retrato de um real, mas interpretações do mundo. É a ideologia se realizando na linguagem. É justamente ao distanciar-se do compromisso de dar conta da verdade jornalística que podemos entender a noção de autoria nos documentários.

\section{Impressões de Cuba}

\footnotetext{
${ }^{11}$ É muito comum o discurso que "a ideia nasceu". Reconhecemos a complexidade dessa formulação, porque o autor não é sujeito de si. O que ele diz é atravessado por outros discursos, que o antecederam (MAIA, 2014).
} 
Impressões de Cuba é uma produção da Globo News, canal fechado (por assinatura) de televisão, do conglomerado midiático brasileiro Organizações Globo. Está indexada como documentário, mas é interessante notar certa confusão da própria emissora, quando insere nos créditos finais a denominação reportagem. Mesmo admitindo que se trate de um documentário jornalístico ${ }^{12}$ - conceito, aliás, discutível -, a denominação contribui para a produção e seus efeitos de sentidos sobre a realidade que o vídeo se propôs mostrar.

Ao assistir à produção como um documentário e não como reportagem, os efeitos são da ordem da profundidade e da humanização, como abordamos. Espera-se que as entrevistas tenham sido fruto de um embate com o outro. Que os atores sociais tenham ganhado voz. Que o documentarista tenha sido de tal maneira impactado pelo processo de produção, que tenha adquirido autoridade para - mais do que apenas informar - analisar, discutir e interpretar dados sobre a temática do documentário. Pelos fatores que elencamos anteriormente a respeito das diferenças entre ambas as produções, documental e jornalística, entendemos que dizer que um produto audiovisual é um documentário ou uma reportagem produz efeitos de sentido diferentes, e a produção Impressões de Cuba, não foge a isso ${ }^{13}$.

A questão que se coloca é que, ao não terem produzido um documentário, mas um produto audiovisual que dialoga com a tradição documental, os autores precisam justificar perante sua audiência as lacunas que a produção não foi capaz de preencher. Por isso, refletiremos sobre a saída encontrada, qual seja o deslocamento do sujeito jornalista para um lugar onde há mais autoridade e maior liberdade interpretativa: a figura do documentarista.

\section{O Sujeito Jornalista/Documentarista}

"Eu sei muito bem o que estou fazendo e assim eu faço", com essa frase o filósofo Slavo Zizek (1999) reflete sobre a ideologia, que segundo o autor, funciona como uma prática. $\mathrm{O}$ ato de dizer sempre a mesma coisa, sempre o mesmo discurso,

\footnotetext{
12 Documentários produzidos no âmbito de veículos de comunicação de imprensa e, mais que isso, orientados a partir de uma pauta e de um enfoque previamente discutidos e definidos pela equipe editorial, como ocorre com as reportagens dos telejornais.

${ }^{13}$ O programa telejornal é composto pela sucessão de notícias, sem haver propriamente uma narrativa que articule sua unidade no todo. Ao contrário da reportagem do programa telejornal, o documentário não está vinculado a acontecimentos cotidianos de dimensão social que denominamos notícia (RAMOS, 2008, p. 59).
} 
materializa uma prática, e será essa prática que se configurará como evidência para o sujeito. As evidências, segundo Althusser (1965), são as relações imaginárias que os sujeitos tecem com a realidade. Pêcheux (1995) define que as formações imaginárias sempre resultam de processos discursivos anteriores, manifestando-se através da antecipação, das relações de força e de sentido. As percepções sobre Cuba pelos jornalistas da Globo são produzidas a partir de outras percepções que as antecederam (MAIA, 2014, p. 16). Os dizeres sobre Cuba aparecem para o leitor como uma novidade, quando são dizeres que se apoiam em uma enunciação histórica (MAIA apud COTRIM, 2016).

O Jornalismo é um bom lugar para pensarmos as evidências às quais o jornalista está submetido, uma vez que as notícias "funcionam como uma intervenção no mundo, um agenciamento que constrói fatos, fatos que compõe a realidade de uma prática" (MAIA, 2014, p. 39). Quando o Jornalismo naturaliza algo, esse ato é um efeito de sentido constituído por um processo histórico "que estabiliza 'verdades' inquestionáveis" (MAIA, 2014, p. 41). Nesse sentido, Cuba já chega para o jornalista como evidência, sustentada por uma prática discursiva, a qual interfere no imaginário dos jornais sobre a ilha.

Quando os jornalistas da Globo News falam sobre Cuba, eles, presos às suas ilusões, às suas evidências, acreditam (e por isso defendem) que sua produção discursiva é isenta e objetiva; esse efeito é produzido pela ideologia (PÊCHEUX, 1999). Os jornalistas que só querem refletir a realidade, não sabem que o fato já chega como linguagem pelo imaginário. "Quando o jornalista vai até a Cuba realizar uma reportagem, a ilha já chegou antes como imagem para o sujeito" (COTRIM, 2016); essa imagem é sustentada por um imaginário que foi produzido historicamente; num processo que não é simplesmente cronológico, mas político. Entretanto, o sujeito não tem consciência disso. Ele acredita ser dono de seu próprio dizer, e por isso não reconhece o atravessamento de outros discursos, que participam desse jogo de dizeres (FOUCAULT, 1999).

O que funciona nos processos discursivos é uma série de formações imaginárias que designam o lugar que A e B se atribuem cada um a si e ao outro, a imagem que eles se fazem de seu próprio lugar e do lugar do outro" (PÊCHEUX in GADET, 1993, p. 82).

Muitas pessoas ainda pensam que as palavras têm um sentido intrínseco e original, ou verdadeiro. Ao contrário, os sentidos são da ordem da história, ou seja, a 
narrativa jornalística sobre Cuba, produzida no presente, é efeito de uma memória que foi construída antes. A memória aqui não tem um sentido psicológico, de lembrança, mas de prática discursiva. Para que os sentidos façam sentido no presente é porque elas já fizeram no passado. Desse modo, o discurso sobre Cuba é constituído, também, das percepções anteriores. Os saberes que se tem um determinado tempo e lugar são sempre...

produzidos a partir de outros que os antecederam e que serão por eles substituídos. Qualquer entendimento novo sobre algo, sempre parte do entendimento anterior- eis aí a noção de devir histórico (MAIA, 2014, p. 16).

A memória discursiva do arquivo da Globo News foi produzida num processo histórico que não é cronológico, mas político. "No mundo da linguagem, os sentidos sobre Cuba também estão em disputa" (COTRIM, 2016). Na correlação de força, alguns sentidos são mais dominantes do que outros, o que não significa que o sentido predominante anule os outros (MARIANI, 1996). Em outras palavras, "a memória discursiva seria aquilo que, em face de um texto que surge como acontecimento a ler, vem restabelecer os implícitos" (PÊCHEUX, 1999, p. 52) (os pré-construídos). O interdiscurso determina o nosso dizer no presente, estabelecendo sentidos como evidentes. Eles são "evidentes", porque, quando se diz algo, "alguma coisa fala antes em outro lugar", como formulou Pêcheux.

Todo mundo sabe o que é um soldado, um operário, um patrão, uma fábrica, uma greve etc., evidências que fazem com que uma palavra ou um enunciado queiram dizer o que realmente dizem e que mascaram, assim, sob a transparência da linguagem, aquilo que chamaremos o caráter material do sentido das palavras e dos enunciados (PÊCHEUX, 1988, p. 160).

A antecipação é a imagem que os jornalistas fazem de Cuba, a qual faz sentido pela memória. A história ${ }^{14}$ traz o passado da enunciação sobre Cuba, que resulta no presente como algo novo ou evidente, original. É nesse ato de enunciar coletivo o momento em que a palavra Cuba é apreendida pelo sujeito/jornalista e pelo sujeito/espectador, provocando um vínculo com o que está sendo enunciado. A enunciação coletiva produz a sensação de compartilhamento, que identifica, pelas práticas discursivas, o momento e o lugar histórico de onde falamos. A linguagem

\footnotetext{
${ }^{14}$ A história, para a análise de discurso, não é cronológica, mas está relacionada às práticas discursivas, ao político. (ORLANDI, 2008).
} 
jornalística que recorta Cuba também é constituída dessa historicidade, sendo o discurso uma prática social concreta. E o jornalista, por sua vez, não é um sujeito que fala a partir da sua experiência empírica, mas um sujeito discursivo, marcado historicamente (FERNANDES, 2008).

\section{O vídeo}

Logo após as imagens de arquivo da Revolução Cubana e do arquivo dos pronunciamentos dos presidentes Barack Obama e Raúl Castro, há uma explicação do editor da editoria Internacional da Globo News, Deni Navarro, e do repórter Rafael Coimbra, a respeito da ideia que originou o documentário e dos procedimentos iniciais para a produção. Mesmo sendo prática comum em alguns documentários que o diretor dê ao espectador o mapa para ajudar a fruição do filme, denotando que o mais importante não é certo suspense que possa ocorrer, mas sim o estabelecimento de uma espécie de regra do jogo, no caso de Impressões de Cuba, tal preâmbulo assume um caráter pedagógico $^{15}$, aproximando-se da linguagem jornalística, com a figura de um enunciador prévio ao conteúdo em si, como os âncoras e apresentadores. Característica da fragmentação, própria do telejornalismo.

Para além do preâmbulo autorreferencial, há na narrativa de Impressões de Cuba um importante deslocamento que merece ser analisado. Deslocar os jornalistas da posição de editor e repórter para o lugar de fonte de informação é bastante simbólico. É interessante notar que o jornalista Rafael Coimbra não figura no vídeo apenas na função de repórter - conduzindo entrevistas e realizando aparições técnicas denominadas passagens, como ocorre em quatro momentos ao longo da produção. Coimbra aparece, muito mais, concedendo entrevista e fazendo uso de uma voz diferente daquela do repórter que apenas informa sobre um assunto. São mais de dez aparições como fonte da informação ao longo do documentário ${ }^{16}$, em que se revezam Coimbra e Navarro.

O problema não está exatamente em atribuir a possibilidade de subjetividade e autoria ao repórter, já que nessa produção ele oscila entre um híbrido de repórter e diretor de documentário. A crítica que tecemos reside no fato de que deslocá-lo para

\footnotetext{
15 A linguagem da Imprensa brasileira funciona como uma espécie de "desenho escolar", o qual, pela repetição, estabelece sua pedagogia, se fazendo "reconhecer, de deixar aparecer sem equívoco nem hesitação aquilo que ele representa" FOUCAULT, 1988, p. 20).

${ }^{16}$ As principais intervenções ocorrem nos seguintes momentos: 5'29”, 8'41', 10'22", 10'38', 12'00”, 14'35', 16'43', 25'04', 35'36', 42'27'”
} 
essa posição, sem retirá-lo da condição de repórter, confere a ele a autoridade de um especialista no assunto.

\section{As evidências sobre Cuba}

Ao dizer, o vídeo produz sentidos e produz silêncios (ORLANDI, 2008). O documentário da Globo News produziu alguns sentidos para Cuba, mas vamos nos concentrar em um sentido mais repetido durante a narrativa global: o sentido de censura. A seguir, trechos selecionados do vídeo para a análise. A escolha se deu pelo campo temático.

T1: Olha, a verdade é que não houve uma grande reação pública, até porque os meios de comunicação aqui são escassos. Não há muitos jornais circulando, eu não vi ninguém lendo jornais, hoje, pelas ruas de Havana. Eu acho que a maior censura de Cuba é técnica (pausa). Você não precisa de alguém monitorando o que você está fazendo se você não consegue nem...nem acessar a internet. Então...a gente perguntava para os cubanos e os cubanos diziam "não tenho internet, eu não sei, eu não vi, eu não li’....porque eu não tive. Então você não precisa nem ter a censura ${ }^{17}$.

T2: A gente foi no Porto de Mariel, tentou produzir a entrada no Porto de Mariel, de tudo quanto é maneira... Ligamos pro local que tinha....Mas é um processo lento e burocrático ${ }^{18}$

T3: nós queríamos muito ir no Porto de Mariel, mas já sabíamos que seria difícil. A nossa alternativa, não tendo autorização, foi ir comendo pelas beiradas. E a gente foi filmando...fica distante de Havana, então foi uma viagem até lá. Quando a gente começou a chegar perto do Porto de Mariel já deu para ver uma movimentação intensa de caminhões.Começamos a filmar e fomos assim....até chegar na porta. E aí...os seguranças se movimentaram e vieram para cima da gente. Mostramos a carteira, que nós estávamos em situação legal, tínhamos autorização e que nós estávamos do lado de fora, tanto é que a gente parou na porta. Esse argumento não convenceu o Segurança; ele foi chamando mais gente, criou-se aquela confusão, eu disse que ele não podia reter nossos passaportes porque ele não era autoridade cubana, ele era um segurança (pausa). Mas, dentro desse argumento, que foi se elevando...porque.... a gente tinha razão, a gente sabia que a gente....podia fazer aquilo. Mas isso não os convenceu. Tinha o risco de a gente ser preso...eu achei, num determinado momento, que a gente seria preso pelo menos para prestar esclarecimentos, porque foi um caos tão grande...Mas eu pensava em....garantir aquele material. Tirei o cartão de memória e coloquei na meia. Escondi o cartão. Não foi preciso, mas a questão só foi resolvida muita tempo depois....quando chegou um militar da

\footnotetext{
${ }^{17}$ Trecho do documentário. Tempo 12`30" a 12`57”. Fala do repórter do documentário.

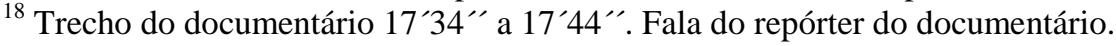


contra inteligência militar cubana, e ele, talvez por não ter visto que a gente já tinha gravado, acabou nos liberando ${ }^{19}$.

O sentido de censura nesses trechos funciona por dois mecanismos: a escassez e o excesso. Ser por um lado, para a Globo News, Cuba tem escassez de informação, de internet e de pessoas (bem) informadas, por outro, o vídeo produzido pela equipe de TV disse tudo o que queria ter dito. No campo da representação, a emissora brasileira é o espaço onde se realiza a liberdade, uma contradição imagética, já que o documentário é produzido em Cuba, lugar da não-liberdade, segundo a narrativa.

Dizer que um país está sob censura e que o trabalho da imprensa é prejudicado por isso não é pouca coisa; as palavras só fazem sentido em contato com os processos históricos, portanto, políticos. A linguagem é efeito desses processos, assim como é o sujeito. Quando o vídeo associa Cuba à ausência de liberdade, lembramos que ser contra a liberdade tem várias faces na história, como o fascismo, o nazismo, as ditaduras militares, governos autoritários, etc. Não é pouco dizer que em um dado país não há liberdade, uma vez que esse enunciado reverbera muitas memórias e heranças discursivas.

Quando o documentário mobiliza a noção de escassez e de censura para representar Cuba, o sentido que Cuba terá para o jornalista da Globo News é o que está alocado em seu imaginário, construído discursivamente, num processo que funciona pela contradição em que o indivíduo é interpelado em sujeito pela ideologia e o que faz com que "todas as evidências, inclusive aquelas que fazem com que uma palavra designe uma coisa ou possua um significado" (ORLANDI, s/d, s/p) façam sentido.

Mas vale abordar o quanto a Globo News (não) dá espaço para a controvérsia, para uma pluralidade de vozes e o quanto ela admite como verdade, e produz um efeito de real, o imediatismo percebido pelo repórter. Estar em Cuba é condição determinante para que o que o vídeo tenha legitimidade. Ser exibido numa emissora como a Globo, já instala o efeito de real no espectador. Se está na TV é porque é verdade (TIBURI, 2011).

O tempo foi uma categoria trazida pelo documentário: “A gente foi no Porto de Mariel, tentou produzir a entrada no Porto de Mariel, de tudo quanto é maneira... Ligamos pro local que tinha....Mas é um processo lento e burocrático" ${ }^{20}$. Esse tempo

\footnotetext{
19 Trecho 18’a 19’24". O trecho seguinte é uma fala do presidente Obama- Fala do repórter do documentário.

${ }^{20}$ Trecho do documentário 17`34" a 1744”. Fala do repórter do documentário.
} 
mexe com o imaginário sobre Cuba e com a educação representacional do jornalista que encontra no visual as respostas para o mundo, funcionando como um método quase pedagógico, "como se fosse uma tentativa de demonstrar para os homens o modelo de sua cultura" (ADORNO, 2006, p. 99:100) em oposição à cultura do outro. São as criações discursivas sobre Cuba que aparecem para o sujeito antes da escrita, quem, no caso, vai legitimar a memória "de que esteve sempre lá".

O trecho sobre o Porto de Mariel ganhou tons de uma reportagem investigativa. A sonoplastia e as imagens em movimento produziram o suspense; em seguida, as formulações dos repórteres: "nós queríamos muito ir no Porto de Mariel, mas já sabíamos que seria difícil (...) Tinha o risco da gente ser preso (...) Escondi o cartão", constrói um cenário de perigo e de medo, diante da complexa tarefa de mostrar um porto, que seja o de Mariel. Qualquer porto do mundo obedece a padrões de segurança, mas a Globo News supõe que isso só existe em Cuba. O jornalista não está se relacionando com Cuba em sua materialidade, mas com a imagem que ele faz de Cuba: "já sabíamos que seria difícil". A narrativa do jornal obedece ao seu imaginário que, sem apresentar controvérsias, carimba Cuba como o lugar da censura. Faz sentido, pelo discurso do documentário, os repórteres terem tido dificuldade de trabalhar na ilha, afinal, eles já sabiam que teriam dificuldades. A frase tinha o risco de a gente ser preso significa pela memória discursiva, produzindo relações de sentido entre Cuba e a censura, acionando um interdiscurso que diz que não há liberdade na Ilha.

A produção da Globo News funciona como um palanque do dizer, que tem a capacidade de condicionar as práticas discursivas dos sujeitos jornalistas, que são, sobretudo, sujeitos históricos, em meio às relações de força de onde os discursos ecoam. O vídeo é a materialidade do conflito entre a produção da Globo News e Cuba, que não é só um conflito político, mas de linguagem. Um conflito ideológico. Dessa maneira, Cuba é um lugar evidentemente escasso. Não tem tecnologia, quiçá tem liberdade:

"Eu acho que a maior censura de Cuba é técnica (pausa). Você não precisa de alguém monitorando o que você está fazendo se você não consegue nem...nem acessar a internet. Então...a gente perguntava para os cubanos e os cubanos diziam "não tenho internet, eu não sei, eu não vi, eu não li’....porque eu não tive. Então você não precisa nem ter a censura ${ }^{, 21}$. Essas formulações produzem alguns efeitos de sentido:

- A maior censura é técnica porque o governo cubano não permite?

${ }^{21}$ Trecho do documentário. Tempo 12`30” a 12`57”. Fala do repórter do documentário. 
- A maior censura é técnica porque Cuba é um país pobre?

- A maior censura é técnica porque Cuba é um país que sofre bloqueio?

Os repórteres não fecharam esses sentidos e por isso eles ficaram migrando. Não dizer (silenciar) os motivos que impossibilitam a internet em Cuba permite que tais formulações se aliem aos já ditos (ao interdiscurso) sobre a censura na ilha. O silêncio nesse caso é uma condição para que as filiações imaginárias com o passado ressurjam e se instalem em outras palavras, como nos enunciados internet e liberdade.

Os enunciados, que tencionam os sentidos sobre internet e liberdade, dizem que quem não está no mundo da internet está atrasado. Cuba ocupa esse lugar do atraso no discurso do vídeo produzido pela Globo News. É o tempo se fazendo presente no espaço. O discurso é de que a internet proporciona a liberdade. E Cuba nem liberdade tem, quanto mais internet.

A ilha alega que por causa das leis do bloqueio econômico não pode se conectar a canais de fibra ópticas internacionais que passam muito perto de suas margens. Os satélites, por outro lado, são muito mais caros e limitam o uso desse recurso. Sempre que Cuba tenta adicionar um novo canal para a internet, a contrapartida dos EUA deve obter a licença apropriada do Departamento do Tesouro dos Estados Unidos. Isso quer dizer que se uma empresa norte-americana quiser abrir um novo canal para Cuba ou aumentar a velocidade da conexão, isso deve ser concedido por uma licença. Não por acaso, com a retomada das relações diplomáticas entre Cuba e os EUA, a conexão na ilha foi anunciado pelo governo estadunidense como uma das medidas tomadas para beneficiar a relação entre os dois países.

\section{Considerações}

Se Cuba já chega como o lugar da censura para os jornalistas, ao olhar a cidade de Havana, o sentido que Cuba terá para o jornalista será o que já existe em seu imaginário. Porque o sujeito, na análise de discurso materialista, é posição (lugar) no mundo para sua posição no discurso "Essa projeção material transforma a situação social (empírica) em posição-sujeito (discursiva)" (ORLANDI, 1999).

Para os jornalistas que foram a Cuba, tomados por suas experiências diretas e imediatas, as coisas na ilha já chegam como significado. Segundo Adorno (2006), há uma homogeneização das percepções; a cultura contemporânea confere a tudo um ar de semelhança: o cinema, o rádio, as revistas constituem um sistema; cada setor é coerente em si mesmo e todos são em conjunto. Nesse mundo semelhante, Cuba aparece, pelo 
discurso, como antagônico. Os jornalistas da Globo News que foram a Cuba trouxeram em seu relato que o País, ao contrário do mundo semelhante, é diferente, mas o discurso do diferente aí vem carregado de marcas linguísticas negativas. E é esse discurso de que Cuba é diferente que faz e fará com que o país seja constantemente alvo de negação.

A produção audiovisual da Globo News materializa essa disputa, que também é discursiva. Não é uma questão só de palavras, imagens e conteúdo, porque é essa disputa que definirá Cuba como "perdedora” nas outras disputas sociais e ideológicas.

\section{Referências:}

ADORNO, Theodor W., HORKHEIMER, Max; Dialética do Esclarecimento: fragmentos filosóficos, Rio de Janeiro, Jorge Zahar Ed., 2006.

ALTHUSSER, L. Marxismo, ciência e ideologia. In: DOMERGUE, R. Marxismo segundo Althusser, p. 10-55. Lisboa: Sinal, 1965.

COTRIM, Amanda. Os discursos sobre Cuba: imprensa, vozes e memória (da atualização do modelo econômico à retomada das relações diplomáticas com os EUA: 2011-2015). Dissertação defendida no Instituto de Estudos da Linguagem, IEL, Unicamp.

FERNANDES, Cleudemar Alves. Análise do discurso: Reflexões introdutórias. São Carlos: Editora Claraluz, 2008.

FOUCAULT, Michel. A ordem do discurso. 2. ed. São Paulo: Edições Loyola, 1999.

FOUCAULT, Michel. Isto não é um cachimbo. Trad. Jorge Coli. Rio de Janeiro: Paz e Terra, 1988.

LAGE, Nilson. Ideologia e Técnica da Notícia. 2 ed. Petrópolis: Vozes, 1982.

MAIA, Carlos Alvarez. História, Ciência e Linguagem. Rio de Janeiro, 2014. Editora Mauad.

MARIANI, Bethania. O comunismo imaginário. Práticas discursivas da imprensa sobre o PCB (1922-1989). Tese (Doutorado em Linguística)- Instituto de Estudos da Linguagem, Universidade Estadual de Campinas, 1996.

MELO, Cristina Teixeira Vieira de. O documentário como gênero audiovisual. Comum. Inf., v.5, n.1/2, p.25-40, 2002.

NICHOLS, Bill. Introdução ao documentário. Campinas: Papirus, 2005.

ORLANDI, Eni. A palavra dança e o mundo roda: Polícia! In: GUIMARÃES, E. (Org) Cidade, Linguagem e Tecnologia.

ORLANDI, Eni. Contextos Epistemológicos da Análise de Discurso, in Escritos, n 4. Campinas, 1999.

ORLANDI, Eni Puccinelli. Discurso, imaginário social e conhecimento. In: Em Aberto, Brasília, ano 14, n.61, jan./mar. 1994

ORLANDI, Eni Puccinelli. (1990) Terra à vista - Discurso do Confronto: Velho e Novo Mundo. $2^{\text {a }}$ Ed. Campinas, São Paulo: Editora da Unicamp, 2008. 
PÊCHEUX, Michel. Análise Automática do Discurso. In: GADET, Françoise (org.). Por uma análise automática do discurso: uma introdução à obra de Michel Pêcheux. 2. ed. Campinas: Editora Unicamp, 1993.

PÊCHEUX, Michel. Contextos Epistemológicos da análise de discurso. In: Escritos. Laboratório de Estudos Urbanos- Nudecri. Nº4, 1999.

PÊCHEUX, Michel. Semântica e discurso: uma crítica à afirmação do óbvio. Tradução de Eni Orlandi, Lourenço C. Jurado Filho, Manoel Luiz G. Corrêa, e Silvana Serrani. $3^{\text {a }}$ edição. Campinas, SP: Editora da Unicamp, 1997. Título original: Les vérités de la Palice, 1975

PÊCHEUX, M. Discurso: estrutura ou acontecimento? Campinas: Pontes, 1990.

PÊCHEUX, Michel. Semântica e discurso: uma crítica à afirmação do óbvio. Unicamp, Campinas, 1995.

PUCCINI, Sérgio. Roteiro de Documentário. Da pré-produção à pós-produção. Campinas: Papirus, 2009.

RAMOS, Fernão Pessoa. Mas afinal...o que é mesmo documentário? São Paulo: Ed. Senac, 2008.

SOUZA, Gustavo. Fronteiras (in)definidas: aproximações e divergências entre documentário e jornalismo. Doc On-Line, n.6, p 158-172, 2009.

TOMAIM, Cássio dos Santos. O ensino do documentário no curso de jornalismo: para transpor as barreiras dos paradigmas da profissão. In: SOSTER, Demétrio de Azeredo. Santa Cruz do Sul: EDUNISC, p. 169-191, 2015.

ZIZEK, S. O Espectro da Ideologia. In: Um mapa da ideologia. Rio de Janeiro, Contraponto, 1999. Disponível em http://petdireito.ufsc.br/wpcontent/uploads/2014/06/link.pdf

ZIZEK, S.. (1989) Como Marx inventou o sintoma? In: ŽIŽEK, S. Um mapa da ideologia. Rio de Janeiro: Contraponto, 1996.

ZIZEK, S. (1990) Eles não sabem o que fazem: o sublime objeto da ideologia. São Paulo: Zahar, 1992.

\section{Documentário:}

Impressões de Cuba. Globo News, 2015. Acesso em outubro setembro de 2015: http://g1.globo.com/globo-news/globo-news-documentario/videos/t/globonewsdocumentario/v/eua-e-cuba-se-reaproximam-em-atitude-historica/4105072/

\section{ARTIGO}

"EUA bloqueiam internet em Cuba", escrito em 2 de novembro de 2006 e publicado no Jornal Juventude Rebelde. Acesso em setembro de 2015: http://www.juventudrebelde.cu/cuba/2006-11-02/estados-unidos-bloquea-internet-en$\underline{\text { cuba-l }}$ 
Data de Recebimento: 26/02/2016

Data de Aprovação: 04/05/2016 


\section{Para citar essa obra:}

SANGION, J. COTRIM, A. B. X. Quando a pauta é Cuba: o jornalista assujeitado às suas evidências, M. Marcher, courir: gestes pour vivre, penser, écrire. In: RUA [online]. no. 21. Volume 2, p. 177 - 186 - ISSN 1413-2109 - Junho/2016. Consultada no Portal Labeurb - Revista do Laboratório de Estudos Urbanos do Núcleo de Desenvolvimento da Criatividade.

http://www.labeurb.unicamp.br/rua/

Capa: CRESTANI, G. Disponível em: https://pixabay.com/pt/espelho-infinito-mulherloira-510976/.

Laboratório de Estudos Urbanos - LABEURB

Núcleo de Desenvolvimento da Criatividade - NUDECRI

Universidade Estadual de Campinas - UNICAMP

http://www.labeurb.unicamp.br/

\section{Endereço:}

LABEURB - LABORATÓRIO DE ESTUDOS URBANOS

UNICAMP/COCEN / NUDECRI

CAIXA POSTAL 6166

Campinas/SP - Brasil

CEP 13083-892

Fone/ Fax: (19) 3521-7900

Contato: http://www.labeurb.unicamp.br/contato 